\title{
PENERAPAN MODEL PEMBELAJARAN JIGSAW UNTUK PENINGKATAN KEMAMPUAN APRESIASI CERPEN
}

\section{Dien Mardiana Yulianti}

\author{
Program Studi Manajemen, Fakultas Ekonomi \\ Universitas Pamulang \\ dosen00155@unpam.ac.id
}

\begin{abstract}
Abstrak
Studi ini dilakukan untuk melihat efektivitas Jigsaw sebagai upaya meningkatkan apresiasi cerpen siswa kelas IX SMP Pelita Bangsa Kota Tangerang Selatan dengan menggunakan Penelitian Tindakan Kelas (PTK). Hasil penelitian menunjukkan bahwa terdapat peningkatan kemampuan melalui model ini. Ratarata nilai awal hanya sebesar 58,75 dalam kategori kurang dan pada akhir siklus I meningkat menjadi 74,60 pada kategori cukup tetapi masih di bawah KKM, dan pada akhir siklus II rata-rata nilai tes siswa sebesar 81,13 termasuk kategori baik. Dari siklus I ke siklus II terdapat kenaikan keaktifan, ketertarikan, dan partisipasi dari $68 \%$ dan pada siklus II meningkat menjadi 84\%. Simpulan dari penelitian ini menunjukkan bahwa model pembelajaran Jigsaw dapat meningkatkan kemampuan apresiasi cerpen siswa kelas IX SMP Pelita Bangsa, Tangerang Selatan.
\end{abstract}

Kata Kunci: apresiasi cerpen, model pembelajaran Jigsaw.

\begin{abstract}
This study was conducted to find out the effectivity of Jigsaw learning model was to increase the appreciation of short stories of students of class IX at the Pelita Bangsa Middle School in South of Tangerang by using action reasearch. The results showed that there was an increase in the ability to appreciate short stories through this model. The average initial score is only 58.75 which is included in the less category and at the end of the first cycle it rises to 74.60 including the sufficient category but still below the KKM, and at the end of the second cycle the average student test score is 81.13 good category. activity, interest, and student participation also increased from cycle I to cycle II, in the first cycle an average of $68 \%$ and in the second cycle increased to $84 \%$. The conclusions of this study are: The application of the Jigsaw learning model can improve the ability to appreciate the short stories of class IX students of SMP Pelita Bangsa, South Tangerang.
\end{abstract}

Keywords: short story appreciation, Jigsaw model in learning

\section{PENDAHULUAN}

Bahasa merupakan sesuatu yang dianggap penting keberadaan dan peranannya. Bahasa merupakan alat komunikasi yang dapat dinikmati semua mahluk hidup di muka bumi ini. Bukan hanya ilmu kebahasaan dan kesastraannya, melainkan juga penggunaannya dalam kehidupan sehari-hari.
Substansi dari mata pelajaran Bahasa Indonesia yaitu bahasa dan sastra. Peserta didik mempelajari keempat keterampilan tersebut dengan memanfaatkan bahasa dan sastra. Selain Bahasa digunakan sebagai alat komunikasi, bahasa juga digunakan untuk mengapresiasi sastra. Agar proses pembelajaran tercapai dengan maksimal diperlukan proses pembelajaran yang 
partisipatif, aktif, kreatif, efektif, menyenangkan, dan bermakna. Untuk itu, guru harus mengusahakan proses pembelajaran sedemikian rupa sehingga akan tercipta pembelajaran yang menyenangkan, efektif dalam penyampaian materi, dan memungkinkan siswa mencapai hasil yang optimal.

Pembelajaran bahasa Indonesia bertujuan untuk meningkatkan keterampilan berbahasa dan bersastra, untuk meningkatkan kemampuan berpikir dan bernalar serta kemampuan memperluas wawasan. (Depdiknas: 2003: 4). Mata pelajaran Bahasa Indonesia merupakan mata pelajaran inti di setiap jenjang pendidikan tentunya harus dikemas dengan efektif dan efisien. Ini terkait dengan tujuan utama mata pelajaran ini, yaitu: agar anak terampil berbahasa dan memudahkan berkomunikasi dengan orang-orang di sekitarnya sehingga mereka dapat beradaptasi dengan lingkungan sosialnya. Terkait dengan substansi mata pelajaran ini, maka tujuan berikutnya adalah memanfaatkan bahasa Indonesia untuk memaknai manfaatnya untuk mengapresiasi suatu karya, dalam hal ini adalah karya sastra. Akan tetapi, ironisnya, guru kurang memahami sehingga materi tentang sastra dianggap sebagai mata pelajaran yang menyulitkan dan mejenuhkan. Ini menunjukkan esensial dari standar kompetensi pembelajaran tersebut terabaikan. Materi pembelajaran sastra belum mencapai tujuan yang maksimal. Hal ini dibuktikan oleh rendahnya penguasaan peserta didik terhadap apresiasi sastra. Nilai mengapresiasi sastra sebagai akhir dari sebuah proses pembelajaran belum memperoleh hasil yang cukup baik. Terbukti soal ujian nasional yang terkait dengan apresiasi sastra masih banyak peserta didik yang salah menjawab sehingga nilai ujian nasional Bahasa Indonesia masih rendah.

Bila ditelusuri lebih detil berdasarkan hasil wawancara dan pengamatan terhadap pembelajaran sebelumnya, peserta didik kesulitan memahami isi cerita, maka hal ini berakibat pada kesulitan menentukan tema cerita. Peserta didik tidak memahami gaya bahasa yang digunakan pengarang sehingga sebagian besar kalimat tidak dipahami secara sempurna. Dengan begitu berefek kepada pemahaman peserta didik terhadap alur cerita, amanat, penokohan, dan setting. Dalam penelitian ini, lebih khusus cerpen dipilih sebagai objek penelitian.

Pembelajaran dianggap berhasil apabila peserta didik dapat mencapai tujuan pembelajaran yang dirumuskan dalam RPP. Untuk memudahkan pencapaian tujuan pembelajaran, guru dapat mengemasnya melalui model pembelajaran. Yang terjadi di lapangan, banyak guru yang mengabaikan pemilihan pendekatan, model, ataupun strategi pembelajaran. Guru kurang menyadari sepenuhnya bahwa model pembelajaran yang kooperatif akan membantunya mentransfer ilmu pengetahuan. Penelitian ini berupaya untuk mencari solusi dengan menggunakan sistem pembelajaran dengan menggunakan kooperatif Jigsaw.

Pembelajaran

kooperatif merupakan sistem pengajaran yang memberikan kesempatan kepada anak didik untuk bekerja sama dengan sesama siswa dalam tugas-tugas yang terstruktur (Lie, 2007: 12). Slavin dalam Saefuddin dan Berdiati (2014: 51) mengungkapkan bahwa "fokus kelompok pada pembelajaran kooperatif dapat mengubah norma-norma dalam budaya anak-anak dan membuat prestasi tinggi dalam tugas-tugas belajar 
akademis lebih dapat diterima." Asma (2006: 14) mengatakan bahwa "dalam pelaksanaan pembelajaran kooperatif setidaknya terdapat lima prinsip yaitu prinsip belajar siswa aktif, belajar kerjasama, pembelajaran partisipatorik, mengajar reaktif, dan pembelajaran yang menyenangkan." Model pembelajaran ini menjadikan siswa termotivasi untuk belajar karena skor-skor yang dikontribusikan para siswa didasarkan pada sistem skor perkembangan individual supaya mereka dapat membantu timnya melakukan tugas dengan baik (Slavin, 2005:5).

\section{METODE PENELITIAN}

Penelitian Tindakan Kelas yang berjudul Peningkatan Kemampuan Apresiasi Sastra melalui model jigsaw pada siswa Kelas IX di SMP Pelita Bangsa Tangerang Selatan tahun ajaran 2016/2017. Pemilihan waktu dan kelas diatur sedemikian rupa agar tidak mengganggu target pembelajaran selama satu semester. Penelitian ini menggunakan teknik observasi. Sutopo (2002: 64) menyatakan bahwa teknik observasi dilakukan untuk menggali data dari sumber data yang berupa peristtiwa, tempat atau lokasi, dan benda serta rekaman. Observasi dilakukan dengan cara mengamati langsung atau melihat lebih dekat tentang (a) keterampilan siswa menulis cerpen melalui model pembelajaran picture and picture, dan (2) tingkat pemahaman siswa mengenai gambar yang disajikan

\section{HASIL DAN PEMBAHASAN Temuan Penelitian Siklus 1}

Penelitian Tindakan Kelas ini telah disesuaikan dengan tahap-tahap dan prosedur yang ditentukan sebelumnya pada rencana tindakan. Dari pelaksanaan PTK ini, diperoleh data yang perlu dievaluasi. Data yang diperoleh berupa hasil observasi dan nilai tes tertulis (tes objektif berupa pilihan ganda).

Observasi dilakukan oleh peneliti dan guru mata pelajaran Bahasa Indonesia yang mengajar di sekolah yang sama. Dari observasi diperoleh permasalahan siswa dalam mengikuti mata pelajaran mengapresiasi unsur intrinsik cerpen. Dari data observasi awal (sebelum siklus 1) diperoleh : (1) kesulitan guru mengajarkan unsur intrinsik cerpen dengan cara yang menyenangkan, (2) pembelajaran diberikan guru dengan ceramah dan pemberian contoh (bersifat konvensional), (3) peserta didik menjawab soal dengan mengandalkan catatan dari guru sebab soal yang diberikan sama dengan yang dicatat, (4) peserta didik kurang termotivasi dalam pembelajaran, (5) peserta didik masih sulit menangkap maksud dari cerita yang dibacanya, (6) kebingungan memahami jalannya cerita, (7) masih ragu-ragu menangkap isi cerita, (8) peserta didik menyatakan sering membaca cerita anak yang bahasanya mudah dipahami. Ini menujukkan bahwa tingkat apresiasi peserta didik masih rendah, baik pada taraf mengenali, memahami, menghayati, atau menikmati, bahkan menerapkan.

Pada siklus 1 yang dilakukan 2 pertemuan untuk menyampaikan materi selama 2 jam pelajaran dengan durasi 40 menit. Selama siklus 1 berlangsung, peneliti mengamati keaktifan peserta didik dalam pembelajaran tersebut. Tes tertulis dilakukan di akhir siklus 1, yaitu hari Selasa, 13 September 2016.

Hasil observasi partisipasi keaktifanpeserta didik selama 2 pertemuan menunjukkan respon yang cukup baik dilihat dari kuesioner, yaitu: (1) antusias menjawab pertanyaan, (2) aktif bertanya, (3) berusaha menanggapi jawaban teman. Dari hasil pengamatan guru selama proses siklus 1 
berlangsung, seperti yang tertera pada grafik berikut ini.

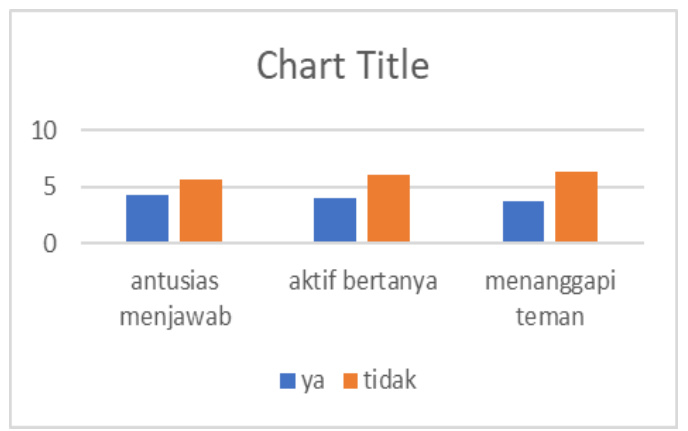

Rata-rata skor nilai tes tertulis mengapresiasi unsur intrinsik cerpen pada penelitian pendahuluan adalah perolehan IX.1 68,80; IX.2 64,68; IX.3 66,24; dan IX.4 62,05. Dapat disimpulkan dari empat kelas terdahulu, tidak ada satu pun kelas yang memiliki nilai rata-rata kelasnya mencapai nilai KKM yaitu $75 . \quad$ Berdasarkan wawancara terdahulu, maka dipilihlah kelas IX.4 yang dijadikan subjek penelitian karena nilai perolehannya paling kecil yakni 62,05.

Setelah dilakukan tindakan pada kelas IX.4 maka hasil tes tertulis (pilihan ganda) diperoleh nilai rata-rata mencapai 75,86. Ada peningkatan sebesar 13,81. Peningkatan rata-rata nilai mengapresiasi unsur intrinsik cerpen ini cukup signifikan. Akan tetapi, belum memuaskan karena masih $75 \%$ angka pencapaian dan di bawah KKM sekolah yaitu 76. Maka perlu dilakukan siklus ke-2.

Berdasarkan 15 pertanyaan dalam kuesioner yang diisi 32 peserta didik menunjukkan bahwa 15 sangat setuju dan 6 setuju masih bingung dengan alur, sisanya 11 sudah paham alur. Ada 15 setuju paham tentang klimaks dan 10 tidak setuju (berarti belum paham klimaks), sisanya 7 raguragu (setelah diwawancarai jawabannya, tergantung ceritanya, kadang-kadang ada cerita yang alurnya susah diikuti). Terkait dengan setting dan penokohan, hasil kuesioner peserta didik menyatakan tidak kesulitan. Apresiasi tema dan amanat masih banyak yang kesulitan, terbukti hasil kuesioner menunjukkan 32 peserta didik masih salah dalam menentukan tema dan 14 sangat setuju, 8 setuju masih sulit menemukan amanat secara implisit. Ini berarti lebih dari $50 \%$ peserta didik kesulitan menangkap makna cerita. Hal ini terjadi karena setiap peserta didik lebih menyukai cerita dengan bahasa yang ringan dan mudah dipahami mencapai 32 siswa, terdapat 10 setuju dan 15 sangat setuju menyatakan tidak menyukai cerita yang menggunakan gaya bahasa. Ini menunjukkan bahwa masih banyak anak yang sulit menangkap isi atau maksud cerita sebab tidak memahami bahasa.

Beberapa temuan di atas akan dijadikan dasar untuk merevisi RPP pada siklus 1 untuk dijadikan RPP pada siklus 2, terutama pada penguasaan makna kata. Pada RPP siklus 2, alokasi waktu saat kegiatan inti akan ditambah dan kegiatan pendahuluan akan sedikit dikurangi. Anggota kelompok akan diperkecil sehingga mengefektifkan diskusi kelompoknya. Anggota kelompok akan diubah sedemikian rupa sehingga lebih heterogen, tetapi saling mendukung.

\section{Temuan Penelitian Siklus 2}

Berdasarkan data pada siklus 2

yang dilaksanakan tanggal 27 September 2016, ada peningkatan skor. Rata-rata skor pada siklus 1 berjumlah 75,86 mengalami peningkatan menjadi 84,81. Terdapat peningkatan sebesar 8,95 . Capaian hasil tes mengapresiasi unsur intrinsik cerpen sebesar 84,81 sudah melampaui Kriteria Ketuntasan Minimal Bahasa Indonesia di SMPN 19 Tangerang Selatan. 
Dari 20 soal tes tertulis terdapat 2 soal tentang alur, 1 soal penokohan, 2 soal amanat atau pesan moral, 2 soal berkaitan denga setting, 2 soal sudut pandang atau point of view, 4 soal tentang gaya, dan 2 soal terkait tema. Penditribusian unsur intrinsik ke dalam soal tes tulis dimaksudkan agar semua unsur terwakili dalam soal tes. Dari 42 peserta ddik di kelas yang mendapatkan tindakan terdapat 6 peserta didik mendapat nilai 100 , ada 4 peserta didik yang nilainya masih di bawah KKM, yaitu dengan nilai 70 dan 2 orang 74 , selebihnya memiliki capaian nilai ratarata 8. Maka dapat disimpulkan bahwa siklus ke-2 dengan tindakan pembelajaran jigsaw untuk materi mengapresiasi unsur intrinsik cerpen dinyatakan sangat berhasil.

Hasil observasi partisipasi keaktifan peserta didik selama 2 pertemuan menunjukkan respon yang baik. Hasil pengamtan peneliti dan guru sejawat pada pembelajaran siklus 2 memperlihatkan adanya peningkatan dalam hal keantusiasan siswa menjawab pertanyaan, keaktifan siswa bertanya, dan keaktifan siswa menanggapi jawaban teman.

Siklus 2 yang dilaksanakan pada tanggal 20 s.d. 23 September 2016 menunjukkan bahwa 32 peserta didik di kelas IX.4 92\% antusias dalam menjawab pertanyaan baik lisan maupun tulis yang diajukan guru. Terdapat 27 siswa aktif bertanya, ini berarti sebanyak $88 \%$ siswa kelas IX.4 bertanya. Ketika diskusi dan presentasi berlangsung, terdapat 32 siswa dari kelompok yang berbeda memberi tanggapan atau komentar atas jawaban teman. Apabila dinyatakan dalam grafik seperti berikut ini.

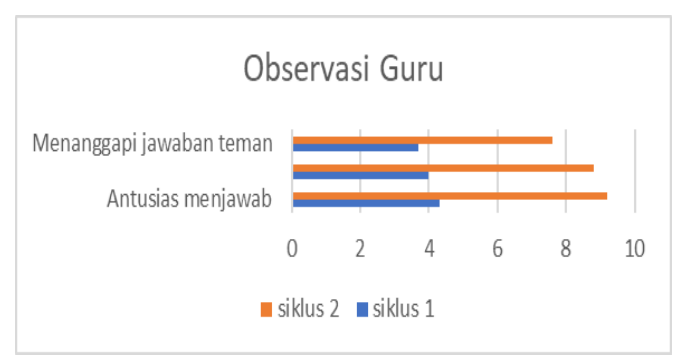

Dari 15 pertanyaan dalam kuesioner yang diisi 32 peserta didik pada siklus 2 menunjukkan bahwa 27 sangat tidak setuju dan 5 tidak setuju terkait pernyataan kebingungan terhadap alur suatu cerpen. Ada 20 sangat setuju dan 12 setuju dengan pernyataan kuesioner paham tahap klimaks suatu cerpen. Terkait dengan kuesioner mempertanyakan pemahaman peserta didik tentang setting dan penokohan terdapat 28 peserta didik memahaminya. Ini berarti ada lonjakan hasil kuesioner setelah siklus 2 . Apresiasi tema dan amanat pada siklus 1 masih ada beberapa yang kesulitan, namun setelah siklus 2, ada 21 peserta didik menyatakan sangat tidak setuju terhadapa pernyataan belum bisa menguasi tema dan 20 peserta didik menyatakan tidak setuju terhadap pernyatan kesulitan menentukan amanat.

Pada siklus 1 ada yang menyatakan setuju bahwa makna cerita sulit ditangkat Karena pemakaian Bahasa yang sulit, pada siklus 2 terjadi penurunan. Peserta didik yang merasa kesulitan menangkap makna cerita berubah menjadi 8 sangat setuju dan 5 setuju. Ini berarti 25 menyatakan sangat tidak setuju, menunjukkan lebih dari $50 \%$ peserta didik tidak lagi kesulitan menangkap makna cerita.

Berdasarkan hasil kuesioner peserta didik yang dilaksanakan pada tanggal 28 September 2016 selama pembelajaran mengapresiasi unsur intrinsik cerpendi kelas IX.4 pada siklus 
2 menunjukkan peningkatan respon positif.

Dari analisis di atas, maka dapat disimpulkan bahwa model pembelajaran jigsaw sangat efektif dan efisien untuk meningkatkan kemampuan peserta didik dalam hal mengapresiasi unsur intrinsik cerpen.

\section{Perbandingan Siklus 1 dengan Siklus 2}

Apabila dibandingkan capaian hasil tes tertulis antara sebelum tindakan (prasiklus), siklus 1, dan siklus 2, diperoleh seperti dalam tabel berikut ini.

\begin{tabular}{|c|c|c|}
\hline Prasiklus & $\begin{array}{c}\text { Siklus } \\
1\end{array}$ & $\begin{array}{c}\text { Siklus } \\
2\end{array}$ \\
\hline 62,05 & 75,86 & 84,81 \\
\hline
\end{tabular}

Bila dicermati pada prasiklus terdapat 7 peserta didik yang berhasil memperoleh nilai tes $\geq 76$, siklus 1 ada 24 peserta didik, dan setelah siklus 2 ada 29 peserta didik. Sebaliknya, peserta didik yang memperoleh nilai tes tertulis $\leq 76$ sebelum siklus 1 ada 25 lalu siklus 1 menurun menjadi 18 dan setelah pembelajaran pada siklus 2 menurun menjadi 4 orang.

Nilai terendah sebelum diberi tindakan 28 dan nilai tertinggi 78. Setelah siklus 1 nilai tes meningkat dengan perolehan nilai terendah 56 dan nilai tertinggi 92 . Setelah siklus 2 perolehan nilai tes makin meningkat menjadi 1 orang mendapat nilai 68 , I orang bernilai 70 , dan 2 orang bernilai 74 .

Temuan pada penelitian ini menunjukkan kemampuan siswa mengapresiasi cerpen meningkat sangat signifikan. Hal ini dapat dibuktikan pada di atas dan bisa ditelaah pada grafik distribusi nilai tes berikut ini.
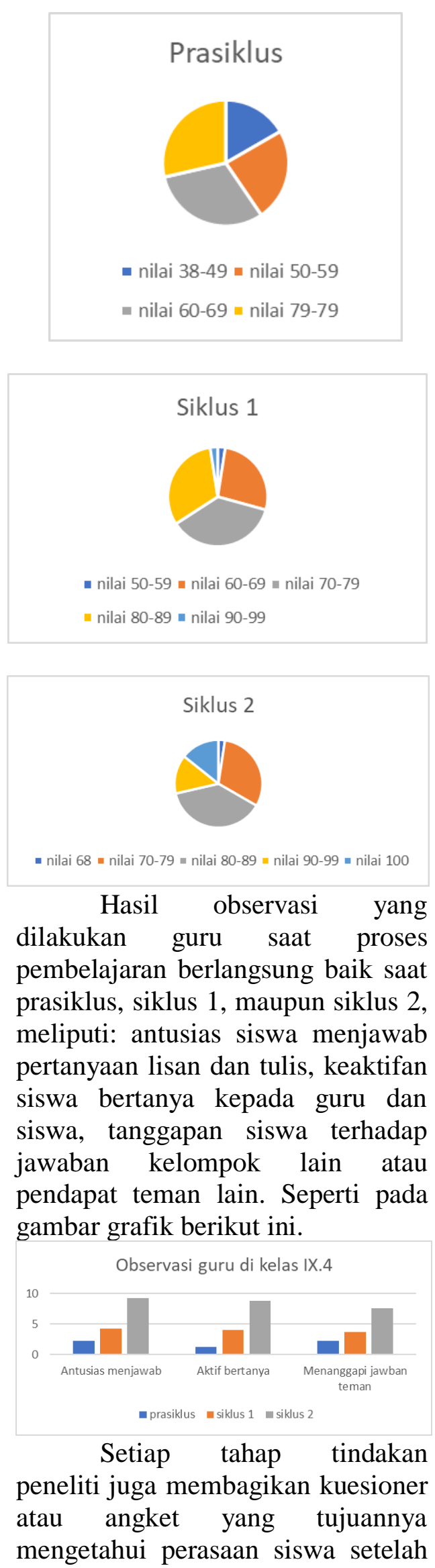
pembelajaran, apakah ada hal yang masih membingungkan atau materi apakah yang sudah dikuasai. Ada 15 pertanyaan terkait penguasaan mengapresiasi cerpen. Dari semua pertanyaan itu merangkum 7 unsur intrinsik, seperti pada grafik berikut ini.

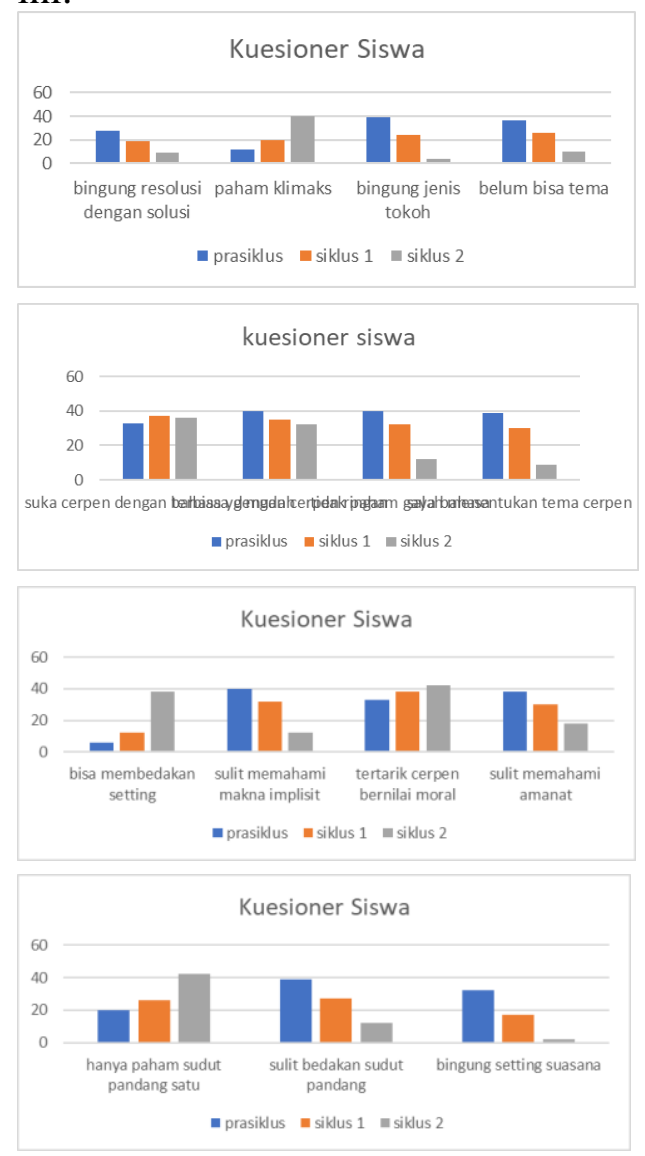

\section{SIMPULAN}

Mengacu pada temuan selama pelaksanaan pembelajaran mengapresiasi cerpen dengan ceramah ternyata membuat anak jenuh dan tidak menguasai materi. Maka dilakukan tindakan pada siklus 1 dan 2. Tindakan yang dilakukan adalah pembelajaran apresiasi cerpen dengan model pembelajaran jigsaw. Dari hasil pengamatan diperoleh kesimpulan bahwa model pembelajaran jigsaw sangat efektif dan efisien dalam meningkatkan kemampuan mengapresiasi cerpen pada siswa kelas IX SMP Pelita Bangsa, Tangerang Selatan tahun pelajaran 2016/2017.

Model pembelajaran jigsaw sangat efektif membuat peserta didik menjadi lebih paham tentang unsur intrinsik cerpen. Tidak hanya kemampuan individu yang meningkat, tetapi juga kecakapan sosial tiap peserta didik terlatih ketika menyelesaikan permasalahan secara berkelompok. Partisipasi siswa dalam proses pembelajaran pun lebih antusias, semangat, dan kondusif. Proses pembelajaran lebih aktif dan menyenangkan.

\section{DAFTAR PUSTAKA}

Lie, A. (2007). Cooperative Learning: Mempraktikan Cooperative Learning di Ruang-Ruang Kelas. Jakarta: PT Gramedia Widiasarana Indonesia.

Saefuddin, A dan Berdiati, I. (2014). Pembelajaran efektif. Bandung: PT Remaja Rosda Karya.

Departemen Pendidikan Nasional. (2003). Kamus Besar Bahasa Indonesia. Jakarta: Balai Pustaka.

Asma, N. (2006). Model Pembelajaran Kooperatif. Jakarta: Departemen Pendidikan Nasional.

Slavin, R. E. (2005). Cooperative Learning (cara efektif dan menyenangkan pacu prestasi seluruh peserta didik). Bandung: Nusa Media.

Sutopo, H.B. (2002). Metodologi Penelitian Kualitatif. Surakarta: Sebelas Maret University Press. 